\title{
PERANCANGAN PERIKLANAN MULTIMEDIA DENGAN TEKNIK SINEMATOGRAFI UNTUK PROGRAM PUBLIKASI (Studi Kasus: Disporabudpar Kabupaten Banyumas)
}

\author{
Ely Purnawati, Prof. Dr. M. Suyanto, M.M \\ Teknik Informatika, MTI STMIK AmikomYogyakarta \\ elypuerto@gmail.com
}

\begin{abstract}
ABSTRAK
Disporabudpar Kabupaten Banyumas membutuhkan video periklanan baru dengan teknik sinematografi yang mampu merepresentasikan kekayaan potensi daerahnya. Penelitian dilakukan dengan membuat 2 buah video iklan dengan teknik sinematografi yang berbeda kemudian diujikan kepada pihak yang berkompeten. Analisis penilaian menunjukkan tingkat penilaian responden ahli terhadap teknik sinematografi yang digunakan pada video pertama (long shot, eye level, panning, low angle dan still camera) mempunyai skor 57,3\% dengan kecenderungan nilai "Cukup" sedangkan video ke-2 (head and shoulders, frog eye, moving track, hot move dan panning) mempunyai skor $88,7 \%$ dengan kecenderungan nilai "Sangat Kuat". Sehingga video kedua terpilih sebagai rekomendasi.
\end{abstract}

Kata Kunci: sinematografi, periklanan multimedia, video iklan, promosi, Banyumas

\section{PENDAHULUAN}

Kabupaten Banyumas dengan keadaan wilayah antara daratan, sungai dan pegunungan menjadikannya mempunyai banyak sumber daya alam yang melimpah. Untuk itu diperlukan sebuah program publikasi berupa periklanan guna mengangkat potensi di daerahnya. Namun sayangnya pada instansi Disporabudpar kabupaten Banyumas sendiri hanya memiliki sedikit sekali referensi video iklan untuk mempublikasikan potensi daerah kabupaten Banyumas.

Berdasar keterangan dari Bapak Djoko Haryanto selaku Kasi Obyek Pemasaran Wisata Disporabudpar Kabupaten Banyumas juga menyatakan bahwa dinas mereka ingin sekali mempunyai sebuah bentuk periklanan dengan format yang kreatif. Pihaknya cukup antusias pada beberapa video iklan yang dibuat oleh dinas-dinas lain, misalnya yang ditayangkan di videotron alun-alun kota, karena dirasa mempunyai teknik pengambilan gambar yang dirasa bagus. Mereka kurang puas dengan teknik-teknik pengambilan gambar yang digunakan pada format 
video sebelumnya. Disporabudpar kabupaten Banyumas berharap pada video selanjunya agar dapat dibuat dengan menggunakan teknik pengambilan gambar yang lebih cocok sehingga lebih dapat menguatkan adegan yang ingin disampaikan.

1. Multimedia

Suyanto (2005) dalam bukunya "Multimedia Alat untuk Meningkatkan Keunggulan Bersaing" menyebutkan, dalam industri elektronika, multimedia adalah kombinasi dari computer dan video (Rosch, 1996).

2. Iklan

Iklan, atau dalam bahasa Inggris "Advertising", adalah suatu bentuk komunikasi massa komersial yang dirancang untuk mempromosikan pemasaran suatu produk atau jasa, maupun pesan dari suatu lembaga, organisasi, bahkan bias juga pesan dari seorang kandidat dalam suatu kampanye politis (Kusrianto, 2009).

Suyanto (2005) membagi tahapan produksi iklan ke dalam berberapa tahap, diantaranya adalah sebagai berikut:

a. Praproduksi, meliputi: mempersiapkan konsep iklan, konsep naskah, storyboard, konsep animasi, konsep efek-efek special, konsep audio dan perencanaan teknik produksi (pemilihan pemain, jadwal produksi, penentuan lokasi dan kegiatan teknis lainnya).

b. Produksi, meliputi: pemilihan kamera, pengaturan pencahayaan, syuting dan perekaman suara.

c. Pascaproduksi, meliputi: pengeditan, pemberian efek spesial, perekaman efek suara, pencampuran audio dan video, persetujuan agensi tempat penyiaran, penggandaan dan penyerahan atau penyiaran.

\section{Video}

Kata video berasal dari kata Latin, yang berarti "saya lihat". Video adalah teknologi permrosesan sinyal elektronik yagn mewakilkan gambar 
bergerak. Istilah video juga digunakan sebagai singkatan video tape, perekam video dan meputar video (Binanto, 2010).

4. Sinematografi

Pada buku Kamus Istilah Televisi dan Film karya Ilham Zoebazary cinematography / sinematografi adalah bidang ilmu yang membahas teknik penangkapan gambar dan penggabungan gambar tersebut sehingga menjadi rangkaian gambar yang dapat menyampaikan gagasan (Zoebazary, 2010).

Adapun beberapa teknik yang dapat digunakan dalam pengambilan gambar diantaranya sebagai berikut:

a. Teknik head and shoulders penonton akan dibawa untuk dapat ikut merasakan apa yang dilihat dari sisi sebelah kepala dan pundak (bahu) tokoh. Alim (2009) menyebut teknik ini sebagai teknik Over The Shoulder Shot (OS) yaitu pengambilan gambar untuk mengambil gambar melalui pundak aktor lain.

b. Long shot $(L S)$ merupakan bidikan kamera jauh, pandangan penuh dari adegan yang dapat memberikan kesan efek luas. Menurut Alim (2009) teknik ini digunakan untuk penekanan terhadap lingkungan sekitar / setting dalam scene.

c. Frog eye akan menjadikan objek terkesan tinggi, kokoh dan megah. Menurut Ispantoro (2011) frog eye merupakan sudut pengambilan gambar diambil sejajar dengan permukaan tempat objek berdiri, seolah-olah memperlihatkan objek menjadi sangat besar.

d. Eye Level / Normal Angle. Kamera ditempatkan sejajar dengan mata subyek. Pengambilan gambar dari sudut eye level hendak menunjukkan bahwa kedudukan subyek dengan penonton sejajar (Javandalasta, 2011). 
e. Low angle merupakan teknik pengambilan gambar dengan posisi kamera lebih rendah dari subjek mata (Alim, 2009).

f. Teknik hot move: fear of high-looking downward penonton akan dibawa ikut merasakan kesan atau sensasi seolah dari tempat kedudukan tempat tinggi.

g. Still camera yaitu teknik pengambilan gambar dengan posisi kamera diam tidak bergerak, menghasilkan kedataran suasana adegan yang mengalir.

h. Panning yaitu membidik dari satu sisi ke sisi yang lain diakhiri bidikan statis (Suyanto, 2004). Teknik pan:hand-off:end on dan switch akan menghasilkan kesan lebih hidup terhadap objek yang bergerak.

i. Tracking yaitu menggerakkan kamera dengan posisi badan kamera turut mengikuti gerakkan yang dijadikan objek. Teknik moving shot track kamera diikutkan bergerak sehingga penonton ikut merasakan pergerakan adegan.

\section{METODE PENELITIAN}

Metode deskriptif analisis adalah statistika yang digunakan untuk menganalisa data dengan cara mendeskripsikan atau menggambarkan data yang telah terkumpul sebagaimana adanya Sugiyono (2012). Metode penelitian yang digunakan dalam penelitian ini adalah metode penelitian survey.

Pengumpulan data yang dilakukan diantaranya yaitu berupa studi literatur, wawancara, observasi dan dokumentasi

\section{HASIL DAN PEMBAHASAN}

Peneliti membuat 2 buah video iklan yang masing-masing menggunakan teknik pengambilan gambar yang berbeda untuk mengambil gambar adegan yang sama. Teknik yang digunakan diambil secara acak yang sekiranya mendekati 
kesesuaiannya dengan adegan. Pada video pertama digunakan kombinasi teknik sinematografi long shot, eye level, panning, low angle dan still camera. Teknik pengambilan gambar pada video pertama itu dibandingkan dengan video ke-dua dimana digunakan teknik head and shoulders, frog eye, moving track, hot move dan panning untuk mengambil adegan yang sama.

1. Produksi Iklan

Konsep tema iklan yang diangkat berupa liputan perjalanan singkat yang eksplorasi potensi daerah yang terdapat di kabupaten Banyumas. Video iklan diberi judul "Paradiso kota Satria" yang menceritakan keindahan sebuah kota Satria (Purwokerto, kabupaten Banyumas) yang walaupun kotanya kecil tetapi kaya akan nilai potensi lokal daerah. Pengambilan gambar yang digunakan berorientasi agar adegan mampu merepresentasikan kekayaan potensi daerah kabupaten Banyumas.

Pada tahap awal praproduksi iklan dilakukan kegiatan seperti mempersiapkan animasi, efek-efek spesial, audio dan perencanaan produksi yang meliputi konsep naskah, pemilihan pemain, jadwal produksi, lokasi dan lain sebagainya. Selanjutnya pada tahapan produksi meliputi kegiatan syuting, perekaman suara, pengaturan pencahayaan dan pemilihan kamera. Proses shooting dilakukan menggunakan gabungan beberapa teknik sinematografi yang disesuaikan dengan kebutuhan adegan. Video dibuat dalam dua buah versi berbeda, dimana konten adegan baik moment ataupun objek dari kedua video tersebut adalah sama hanya saja akan diambil dengan teknik sinematografi yang berbeda. Hal ini untuk membuktikan bahwa teknik sinematografi mampu berpengaruh walaupun moment ataupun objek adegan yang diambil adalah sama. Pada video pertama digunakan teknik sinematografi long shot, eye level, panning, low angle dan still camera dan pada video ke-dua digunakan teknik head and shoulders, frog eye, moving track, hot move dan panning untuk adegan yang sama.

Pada tahap pascaproduksi meliputi kegiatan pengeditan, pemberian efek spesial, perekaman efek suara, pencampuran audio dan video. Hasil dari proses editing dilakukan revisi terlebih dahulu hingga produk siap digunakan untuk 
selanjutnya diteruskan pada proses persetujuan agensi tempat penyiaran, penggandaan dan penyerahan atau penyiaran.

2. Pengujian Responden

Produk iklan yang telah jadi kemudian dilakukan pengujian terhadap responden. Responden yang digunakan dalam penelitian adalah pihak-pihak yang berkompeten ahli dalam lingkup sinematografi seperti director, assistant director dan DOP (director of photography). Responden sebanyak 5 diambil dari studio atau rumah produksi lokal di Indonesia. Salah satu studio yang dipilih berlokasi di Yogyakarta yaitu MSV Studio yang merupakan studio yang terkenal di Indonesia dengan karyanya "Battle Of Surabaya". Disamping itu responden berasal dari beberapa studio lain yang berlokasi di Jawa Tengah yaitu AMPU Studio Purwokerto, Silent Studio, Bhinneka Production dan Art Division Production.

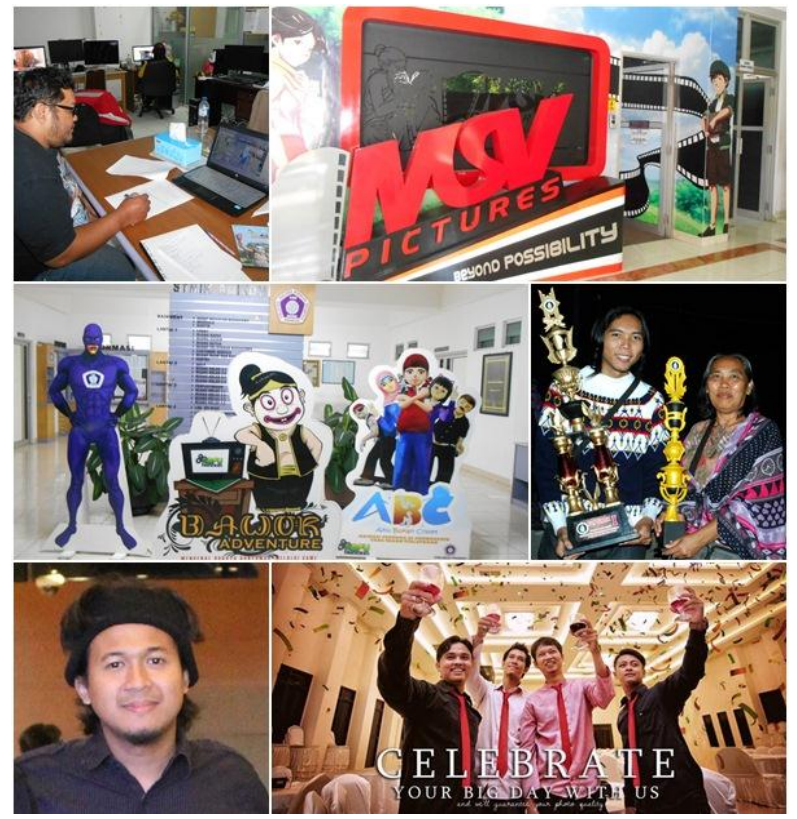

Gambar 1. Profil responden ahli

\section{Analisis Data}

Tipe pengukuran yang digunakan adalah skala Likert yaitu skala yang digunakan untuk mengukur sikap, pendapat dan presepsi seseorang atau sekelompok orang tentang fenomena sosial (Sugiyono, 2012). Pengukuran sikap responden di dalam skala ini dibedakan menjadi 5 tingkatan, yaitu Sangat 
Setuju/SS (skor 5), Setuju/S (skor 4), Netral/N (skor 3), Tidak Setuju/TS (skor 2) dan Sangat Tidak Setuju/STS (skor 1). Data dari para responden ahli kemudian diuji validitas dan reliabilitasnya. Hasil pengujian menunjukkan bahwa semua instrumen yang digunakan memliki nilai validitas dan reliabilitas yang tinggi.

Data selanjutnya dianalisis untuk mengetahui posisi penilaian dari kedua video yang diujikan. Total skor didapat diolah dengan cara mengkalikan setiap point jawaban kemudian dijumlahkan. Nilai index \% dapat dicari dengan menentukan jumlah nilai maksimal dan minimal skor terlebih dahulu. Dari hasil akhir yang didapatkan kemudian ditarik kesimpulan berdasar kriteria interpretasi skornya berdasarkan interval dari masing-masing video iklan. Kriteria persentase tanggapan responden dibagi menjadi 5 kelas interval (Narimawati, 2010).

Tabel 1. Kriteria Persentase Penilaian Responden

\begin{tabular}{|c|c|l|}
\hline Interval & Skor & \multicolumn{1}{c|}{ Keterangan } \\
\hline 1 & $20,00-36,00 \%$ & Sangat Lemah (Tidak Setuju, Buruk / Kurang Sekali) \\
\hline 2 & $36,01-52,00 \%$ & Lemah = Tidak Setuju atau Kurang Baik \\
\hline 3 & $52,01-68,00 \%$ & Cukup atau Netral \\
\hline 4 & $68,01-84,00 \%$ & Kuat = Setuju, Baik atau Suka \\
\hline 5 & $84,01-100 \%$ & Sangat Kuat (Setuju, Baik, Suka) \\
\hline
\end{tabular}

Berikut ini beberapa hasil tampilan video yang telah dibuat:

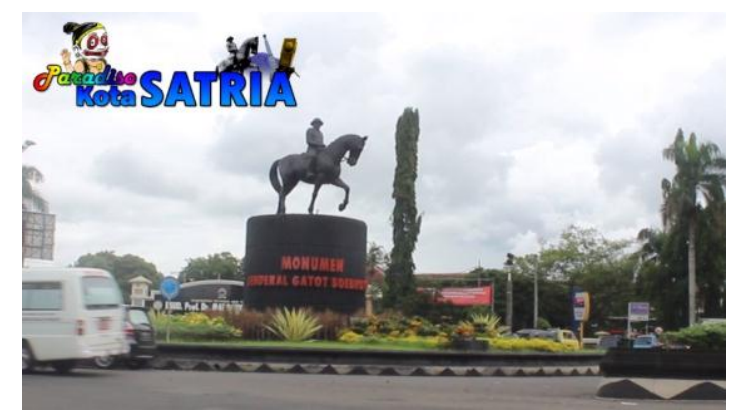

Gambar 2. Hasil adegan judul 


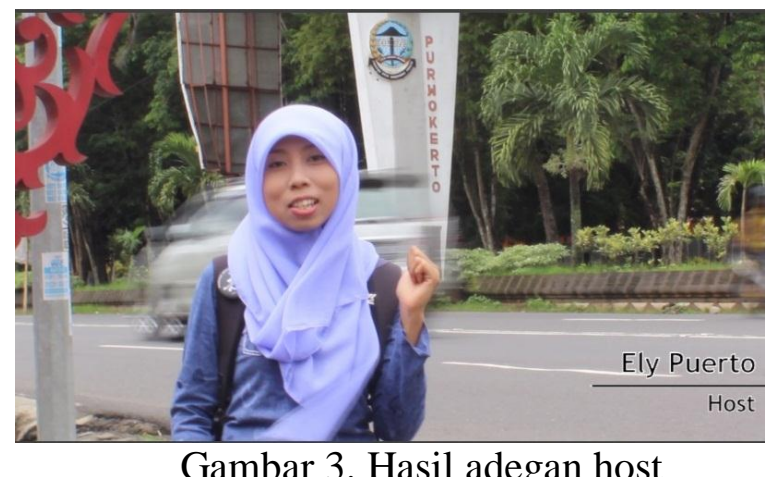

Gambar 3. Hasil adegan host

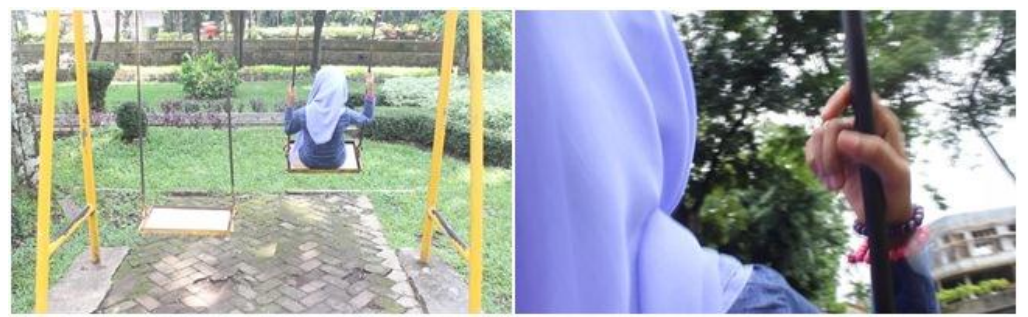

Gambar 4. Perbandingan teknik sinematografi pada adegan ayunan

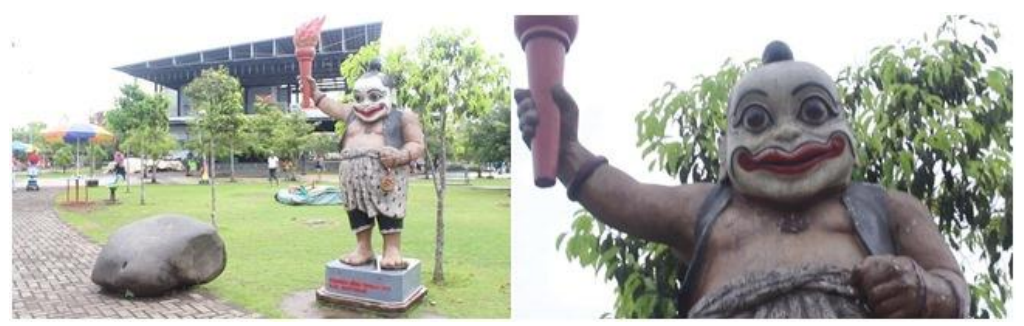

Gambar 5. Perbandingan teknik sinematografi pada adegan patung Bawor

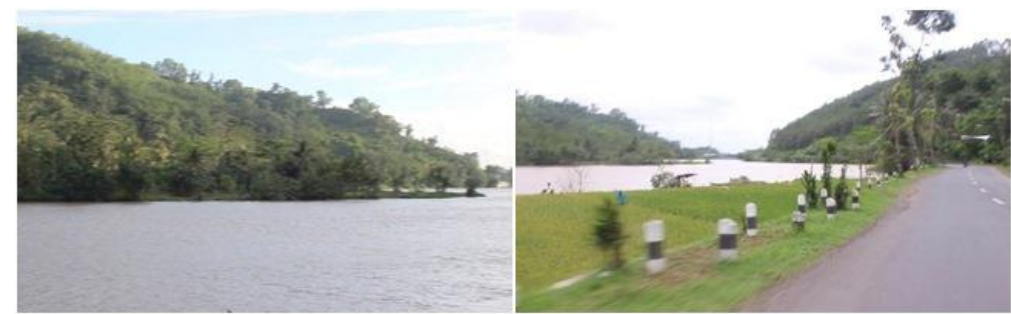

Gambar 6. Perbandingan teknik sinematografi pada adegan kawasan sungai Serayu

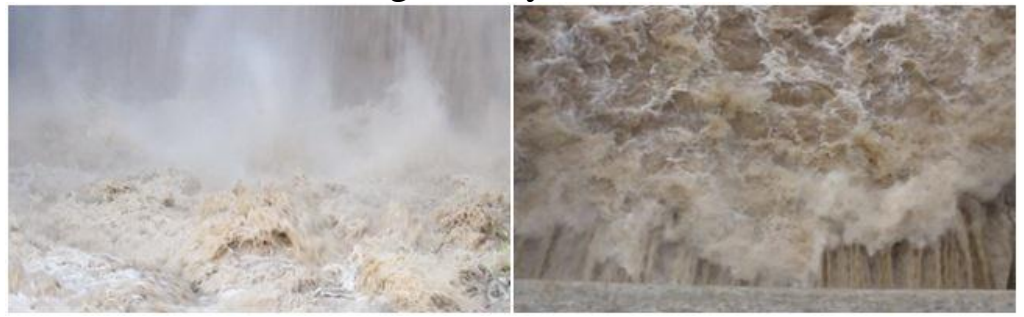

Gambar 7. Perbandingan teknik sinematografi pada adegan pintu air 


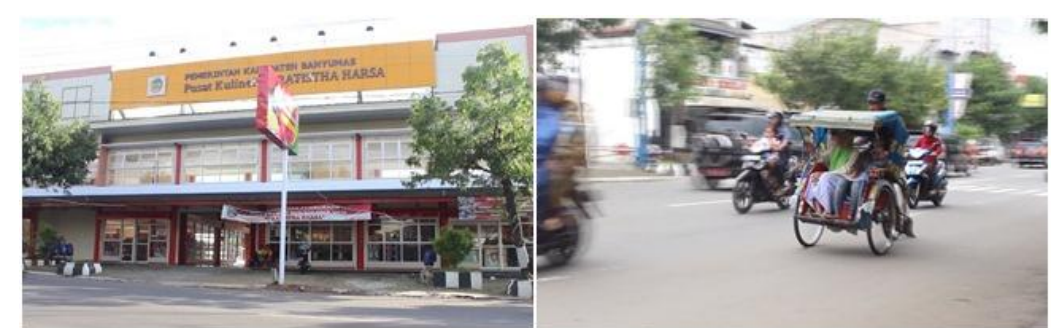

Gambar 8. Perbandingan teknik sinematografi pada adegan kawasan Pratista Harsa

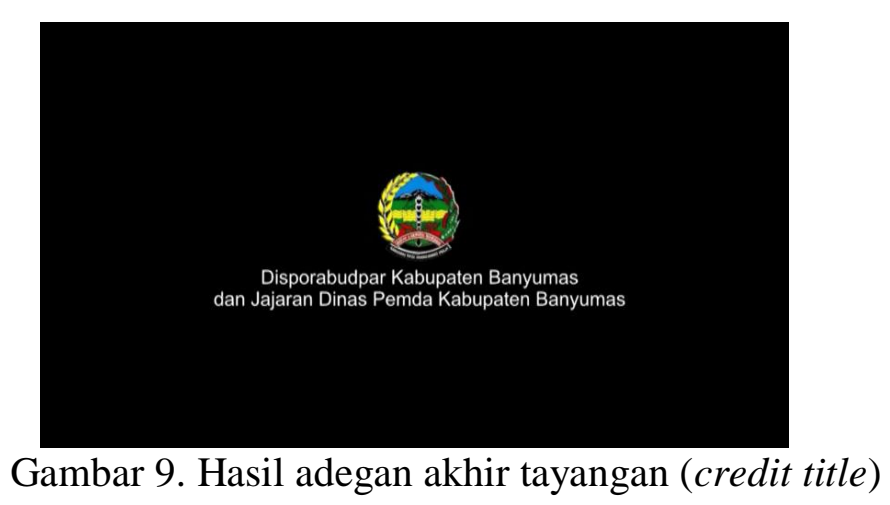

Berdasarkan hasil penilaian yang telah dilakukan berikut ini adalah perbandingan antar teknik pengambilan gambar yang digunakan dari kedua video untuk mengambil adegan yang sama:

a. Dibandingkan nilai teknik head and shoulders pada video iklan pertama dengan teknik head and shoulders pada video iklan ke dua lebih berhasil memberikan kesan seolah membawa penonton untuk dapat ikut merasakan apa yang dilihat dari sisi sebelah kepala dan pundak (bahu) tokoh.

b. Perbandingan nilai teknik eye level pada video pertama lebih rendah teknik frog eye pada video ke dua di adegan icon patung Bawor. Teknik frog eye akan menjadikan objek terkesan tinggi, kokoh dan megah.

c. Pada adegan di kawasan sungai Serayu hasil penilaian teknik panning video pertama lebih rendah dibandingkan dengan teknik moving track shot yang digunakan pada video ke dua. Teknik moving track shot kamera diikutkan bergerak sehingga penonton akan ikut merasakan pergerakan 
adegan. Selain itu penonton jadi lebih mengetahui pemandangan dan rute yang dilewati di sekitar kawasan sungai Serayu.

d. Penilaian terhadap teknik low angel di video pertama lebih sedikit dibandingkan dengan teknik hot move di video ke dua pada adegan pintu air bendungan Serayu. Pada teknik hot move dengan detail hot move: fear of high-looking downward penonton akan dibawa seolah ikut merasakan kesan atau sensasi seolah dari tempat kedudukan tempat yang tinggi.

e. Hasil penilaian teknik panning hand-off: end on dan switch pada video iklan yang ke dua lebih tinggi dibandingkan teknik still camera yang digunakan pada video pertama. Suasana di sekitar kawasan Pratistha Harsa akan lebih terungkap atau seolah dapat dirasakan lebih hidup dengan teknik panning seperti hand-off: end on dan switch.

\section{Interpretasi Hasil}

Secara keseluruhan kombinasi dari semua teknik pengambilan gambar yang digunakan pada video pertama mempunyai hasil penilaian yang lebih rendah dibandingkan dengan teknik yang dipakai dalam video yang ke dua. Setelah dilakukan analisis data kedua video mempunyai perbandingan skor 57,3 : 88,7\%.

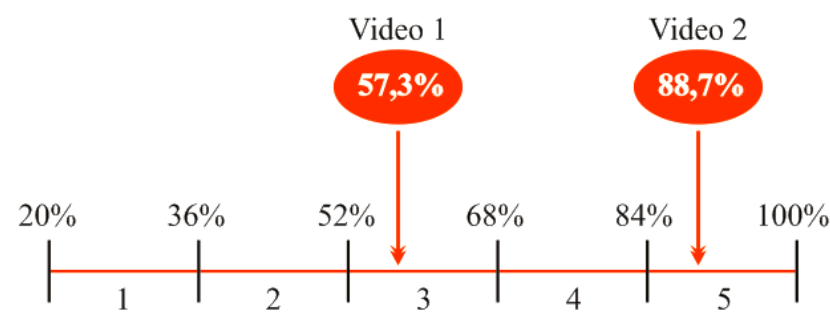

Gambar 10. Perbandingan posisi interval kriteria persentase penilaian responden ahli pada video iklan pertama dan ke dua

Dari Gambar 10 di atas diketahui bahwa penilaian video pertama dengan teknik long shot, eye level, panning, low angle dan still camera mempunyai skor sebesar 57,3\%. Posisi hasil penilaian ini masuk ke dalam interval kelompok ke-3 
yang memiliki kecenderungan nilai "Cukup" atau dapat juga dikatakan bahwa perolehan skor 57,3\% mempunyai nilai "Netral".

Dibandingkan dengan video sebelumnya video ke dua teknik head and shoulders, frog eye, moving track, hot move dan panning mempunyai hasil perhitungan skor yang lebih tinggi yaitu sebesar $88,7 \%$. Skor penilaian ini masuk ke dalam kelompok interval ke-5 yang memiliki kecenderungan nilai "Sangat Kuat (Setuju, Baik, Suka)”.

Berdasarkan perbandingan hasil penilaian responden ahli pada kedua video dimana perbedaan skor yang cukup signifikan dimana dapat disimpulkan bahwa teknik yang digunakan pada video ke dua lebih berhasil mencapai nilai yang lebih tinggi dibandingkan dengan video pertama. Dengan demikian video yang direkomendasikan untuk dijadikan media periklanan multimedia untuk program publikasi pada Disporabudpar kabupaten Banyumas adalah video ke dua dengan teknik sinematografi yang digunakan yaitu teknik head and shoulders, frog eye, moving track, hot move dan panning.

\section{KESIMPULAN DAN SARAN}

Berisi ringkasan dan penegasan penulis mengenai hasil penelitan dan pembahasan. Saran dapat berisi tindakan praktis, pengembangan teori baru dan penelitan lanjutan.

Berdasar tahapan-tahapan yang telah dilakukan maka penelitian ini memperoleh kesimpulan:

1. Periklanan multimedia dengan teknik sinematografi untuk program publikasi potensi daerah kabupaten Banyumas dapat dilakukan dengan cara membuat 2 buah video iklan dengan teknik sinematografi yang berbeda kemudian diujikan kepada pihak yang berkompeten.

2. Setelah diadakan analisis penilaian maka diketahui bahwa tingkat penilaian responden ahli terhadap teknik sinematografi pada video iklan pertama lebih rendah dibandingkan dengan video ke-2. Video pertama dengan teknik long shot, eye level, panning, low angle dan still camera mempunyai skor $57,3 \%$ yang memiliki kecenderungan interval nilai 
"Cukup atau Netral" sedangkan video ke-2 dengan teknik head and shoulders, frog eye, moving track, hot move dan panning mempunyai skor $88,7 \%$ yang memiliki kecenderungan interval nilai "Sangat Kuat (Setuju/Baik)". Dengan demikian video kedua terpilih untuk dijadikan sebagai rekomendasi media periklanan multimedia untuk program publikasi pada Disporabudpar kabupaten Banyumas

\section{DAFTAR PUSTAKA}

Alim, Y. (2009). 60 Menit Mahir Mengedit Video Dengan Pinnacle Studio. Bekasi: Dunia Komputer.

Binanto, I. (2010). Multimedia Digital: Dasar Teori dan Pengembangannya. Yogyakarta: Andi.

Javandalasta, P. (2011). 5 Hari Mahir Bikin Film. Surabaya: Mumtaz Media.

Kusrianto, A. (2007). Pengantar Desain Komunikasi Visual. Yogyakarta: Andi.

Narimawati, U. (2010). Riset Manajemen Sumber Daya Manusia. Jakarta: Agung Media12.

Razaq, A., \& Ispantoro. (2011). The Magic Of Movie Editing. Jakarta: Mediakita.

Sugiyono. (2012). Metode Penelitian Pendidikan Pendekatan Kuantitatif, Kualitatif dan $R \& D$. Bandung: Alfabeta.

Suyanto, M. (2004). Analisis \& Desain Aplikasi Multimedia untuk Pemasaran. Yogyakarta: Andi.

Suyanto, M. (2005). Multimedia Alat untuk Meningkatkan Keunggulan Bersaing. Yogyakarta: Andi.

Suyanto, M. (2005). Strategi Perancangan Iklan Televisi Perusahaan Top Dunia. Yogyakarta: Andi.

Zoebazary, I. (2010). Kamus Istilah Televisi dan Film. Jakarta: Gramedia. 